\title{
EDITORIAL \\ Professional ethics are needed to be a good physician
}

During the Ethics Commissions National Meeting held in Coruna in June 2013, García Guerrero at al. presented a session under the title "Professional deontology and medical practice in prisons" which concluded that "physicians at prisons have little understanding of what professional ethics is" and which reflected that "only $42(35.6 \%)$ are aware of the existence of the Code of Medical Ethics and only 37 $(31.3 \%)$ bave read it and comply with it". ${ }^{1}$

The communication was complemented with a variety of results, with regard to more specific aspects of deontology, yet I believe that the two aforementioned results are valid as to reflect on and write these lines. I intend not only to highlight the importance of professional ethics in everyday medical practice but to state the need and the obligation to comply with the rules of conduct established by the very Code of Medical Ethics, regardless of the fact that medical practice is developed in a detention facility since as the Code establishes itself "the imposed duties are binding on all physicians in the exercise of their profession regardless of the mode in which this is developed".

The need to know and comply with deontology standards is based on the fact that medical ethics are grounded in physicians themselves to inspire and guide their professional conduct. This is a so called native product, this is to say, created by physicians as an answer and guarantee to the inviolable pact between the society and the medical profession. Moreover, another key issue which should not be forgotten is that medical ethics protects the independence of the profession before political power, which cannot and should not interfere which the fulfillment of ethical and deontological mandates ${ }^{2}$.

Hence the need to be aware of and earnestly defend the regulating issues gathered in the Code of Medical Ethics, since they keep the essence of the medical professional intact, free of political or legislative interference, which somewhat tries or has tried to undermine professional freedom or even restrict its self-regulating autonomy. Yet we should not forget the need of and the obligation to justify medical actions in an unconditionally responsible way.

Obviously, physicians as human beings are regulated by common ethics. However, physicians in general and those exercising their profession in prisons in particular, deal with people who suffer from some kind of disease and in so called "abnormal" conditions.

If already the existing doctor-patient relationship is inherently unbalanced and asymmetrical, regardless of what many say, within correctional facilities this is even more so.

Within this relationship, physicians have a really advantageous position and therefore they should appear moderate when exercising their "power", yet as far as defending their moral duties they cannot and should not be moderate, since they are held liable by professional principles.

While it is true that in this correctional background many doubts and medical-professional dilemmas arise, with regard to whether what is being done is right or wrong, prison practitioners must face these issues despite not finding the correct answer at times, therefore creating individual conflicts of conscience and hence, entailing a constant challenge.

Therefore some type of valid "resolution and guiding methodology" should be used. This is represented by the Code of Medical Ethics which includes practitioners' duties and patients' ethical and moral rights, protecting individuals against all types of abuse and not only those prohibited by law. Moreover, it plays a role of recommendation and primarily illumination guide.

Of course I am aware of the particular characteristics of physicians within the correctional system, as far as issues such as their duties regarding the institution o the established hierarchy, are concerned, which entails a so called "twofold fidelity" conflict $^{3}$. Yet when taking professional decisions these should comply with the "professional ethos" since otherwise practitioners could become some type of henchmen subservient to the State, a fact which if I am allowed to say so is a serious mistake of unpredictable consequences.

When I teach my students Medicine's legal and deontology issues I insist that while many practitioners believe that these issues are detached from their professional activity, in fact they are some of the matters which will always be there throughout their careers. While scientific issues may 
change, progress and what we learn today may not be appropriate tomorrow; ethical matters will always be present and common to any medical specialty which they may develop.

Maybe due to that permanency we cannot qualify medical ethics and deontology as matters exclusive to older retired or educational practitioners. It is the opposite: it is a dynamic ceaselessly ongoing discipline which adapts to new circumstances entailed by both social and legal changes regarding the practical exercise of Medicine.

Coming to the end now and if I may say so, I also tell my students that in order to be a true physician it is not good enough to understand a particular discipline, this has to become an useful medical knowledge and the only way to do so is to incorporate it and make use of it. Something as easy yet difficult means that it is not good enough to know that the Code of Medical Ethics exists, but that it is worth reading, commenting, discussing and obviously implementing it.

Implementing the Code can obviously be done right or wrong. Therefore, as to decide whether it is used correctly or not, to come to a judgment or to assess a decision, a standard or system for comparison is needed. The actions taken by physicians and moreover, their conduct has to be framed by their own system of values and that of the medical practice, before which it is not enough to stand as passive individuals. Physicians must know, adapt and make use of the regulations and fulfill their social duties.

This approach would mean that being a physician, being a good one entails the understanding and implementation of ethical standards. Hence the need to elaborate on basic ethical and deontology aspects which guide the exercise of this profession, since it is not good enough to enforce the law to be a physician.

Mariano Casado Blanco Secretary of the WTO Central Committee of Deontology

\section{BIBLIOGRAPHICAL REFERENCE}

1. García Guerrero J, Vera-Remartínez EJ. Deontología profesional y ejercicio médico en prisiones. Comunicación oral en XII Jornadas Nacionales de Comisiones de Deontología; 2013 Jun 13-15; A Coruña.

2. Herranz Rodríguez G. La veracidad ante el error médico es un deber ético. Actualidad del derecho sanitario. 2012; 193: 293-6.

3. García Guerrero J. Apuntes éticos sobre el ejercicio de la medicina en prisión. Rev. esp. sanid. penit. 2009 jul-oct; 11(2): 33-6.

4. Gual Sala A. Aprender a ser médico: responsabilidad social compartida. Madrid: Fundación Educación Médica FEM; 2012. 